\title{
Analisis Penerapan Peraturan Pemerintah Republik Indonesia Nomor 7 Tahun 2011 Tentang Pelayanan Darah Di Palang Merah Indonesia (PMI) Kabupaten Kutai Kartanegara Tahun 2018
}

Annisa Fajriagustia', Tumpak Sinaga ${ }^{\mathbf{2}}$ Hidayatullah $^{\mathbf{3}}$
fajriaannisa@rocketmail.com, Universitas Widya Gama Mahakam, Indonesia ${ }^{1}$
siganatumpak@yahoo.com, Dinas Kesehatan Provinsi Kalimantan Timur, Indonesia

Abstrak

Latar Belakang:

Pemerintah telah menetapkan PP. Nomor 7 Tahun 2011, tentang pelayanan darah.

Tujuan :

Penelitian ini bertujuan untuk mengetahui penerapan PP. Nomor 7 Tahun 2011 Tentang Pelayanan Darah di Palang Merah Indonesia (PMI) Kabupaten Kutai Kartanegara.

\section{Metode Penelitian:}

Penelitian ini menggunakan metode kualitatif dengan pendekatan studi kasus. Sumber informasi didapatkan dari 4 informan yaitu Bidang Quality Control, Kepala Bidang Pencarian dan Pelestarian Donor Darah Sukarela, Bidang Penunjang Medik dan Pendonor Darah.

Hasil :

Hasil penelitiannya adalah belum diterapkannya penyusunan rencana kebutuhan darah. Telah diterapkannya kegiatan pengerahan pendonor darah, namun belum menerapkan kegiatan pelestarian pendonor darah.

Kesimpulan:

Penyediaan darah telah diterapkan dengan baik, namun belum tersedia tempat pemusnahan darah dan pendistribusian darah yang telah diterapkan dengan baik.

Kata Kunci : Peraturan, Pelayanan Darah, PMI.

Abstract

Background:

The government has set Government Regulation Number 7 of 2011, about blood services.

objectives:

The study aimed to decide the application of Republic Indonesia Government Regulation Number 7 of 2011 about Blood Services at the Indonesian Red Cross (IRC) Kutai Kartanegara Regency.

Research Metodes:

This research used qualitative with a case study approach. Sources of information were obtained from 4 informants namely the Quality Control Sector, Head of Search and Preservation of Voluntary Blood Donors, Medical Support and Blood Donors.

Results:

The results that the plan for blood needs has not been implemented. The activities of mobilizing blood donors have been implemented, but the activities of blood donor conservation have not implemented.

Conclusion:

Provision of blood has been applied well, but there is no place for blood destruction and blood distribution that has been applied properly.

Keywords : Regulations, Blood Services, Indonesian Red Cross

DOI $\quad:$ http://dx.doi.org/10.24903/kujkm.v5i1.826

\begin{tabular}{|c|c|c|}
\hline Received & : & March 2019 \\
\hline Accepted & . & April 2019 \\
\hline
\end{tabular}




\section{PENDAHULUAN}

Pelayanan di bidang kesehatan merupakan salah satu bentuk pelayanan yang paling dibutuhkan masyarakat. Palang Merah Indonesia (PMI) adalah salah satu pelayanan kesehatan yang berperan penting bagi masyarakat. Palang Merah Indonesia (PMI) merupakan sebuah organisasi perhimpunan nasional di Indonesia yang bergerak dalam bidang sosial kemanusiaan terutama bagi masyarakat yang membutuhkan transfusi darah, hal tersebut menjadikan betapa pentingnya PMI untuk melaksanakan pelayanan transfusi darah yang aman, bermanfaat, mudah diakses, dan sesuai dengan kebutuhan masyarakat.

Transfusi darah menjadi komponen penting dalam pengelolaan pasien dengan luka pada kasus kecelakaan, kondisi bedah, keganasan, komplikasi kehamilan, dan kondisi medis yang lainnya. Di negaranegara berpenghasilan tinggi, kelompok pasien yang paling sering ditransfusi adalah lebih dari 60 tahun, terhitung hingga 79\% dari semua transfusi. Di negara-negara berpenghasilan rendah dan menengah, ini lebih sering digunakan untuk menangani komplikasi terkait kehamilan, malaria masa kanak-kanak yang dipersulit oleh anemia berat, dan cedera terkait trauma (WHO, 2018).

Transfusi darah menyelamatkan nyawa dan meningkatkan kesehatan, tetapi banyak pasien yang membutuhkan transfusi tidak memiliki akses yang tepat ke darah yang aman. Pengujian tidak dapat diandalkan di banyak negara karena persediaan alat uji yang tidak teratur, kekurangan staf, alat tes kualitas buruk, atau kurangnya kualitas dasar di laboratorium. Risiko penularan infeksi serius, termasuk HIV dan hepatitis, melalui darah yang tidak aman dan kekurangan darah kronis membawa perhatian global pada pentingnya keamanan dan ketersediaan darah. Dengan tujuan memastikan akses universal ke darah yang aman dan produk darah (WHO 2018).

Ketersediaan darah untuk donor, secara ideal adalah 2,5\% dari jumlah penduduk pertahun. Sehingga jika jumlah penduduk di indonesia sebesar 247.837.073 jiwa, maka idealnya dibutuhkan darah sebanyak : $0,025 \times 247.837 .073=$ 4.956.741 kantong darah. Akan tetapi pada tahun 2013 lalu jumlah darah yang terkumpul dari donor sebanyak 2.480. 352 kantong darah. Sehingga secara nasional 
terdapat kekurangan kebutuhan darah sejumlah : $4.956 .741-2.480 .352=$ 2.476.389 kantong darah (Kemenkes RI, 2014).

Transfusi darah menyelamatkan nyawa dan meningkatkan kesehatan, tetapi banyak pasien yang membutuhkan transfusi tidak memiliki akses yang tepat ke darah yang aman. Pengujian tidak dapat diandalkan di banyak negara karena persediaan alat uji yang tidak teratur, kekurangan staf, alat tes kualitas buruk, atau kurangnya kualitas dasar di laboratorium. Risiko penularan infeksi serius, termasuk HIV dan hepatitis, melalui darah yang tidak aman dan kekurangan darah kronis membawa perhatian global pada pentingnya keamanan dan ketersediaan darah. Dengan tujuan memastikan akses universal ke darah yang aman dan produk darah (WHO 2018).

Pelayanan transfusi darah sebagai salah satu upaya kesehatan dalam rangka penyembuhan penyakit dan pemulihan kesehatan sangat membutuhkan ketersediaan darah atau komponen darah yang cukup. Salah satu upaya pelayanan kesehatan terutama dibidang pelayanan darah yaitu menyelenggarakan Peraturan Pemerintah Nomor 7 tahun 2011 tentang pelayanan darah yang bertujuan memenuhi ketersediaan darah yang aman untuk kebutuhan pelayanan kesehatan, memelihara dan meningkatkan mutu pelayanan darah, memudahkan akses memperoleh darah untuk penyembuhan penyakit dan pemulihan kesehatan, serta memudahkan akses memperoleh informasi tentang ketersediaan darah.

\section{METODE PENELITIAN}

Penelitian ini menggunakan metode kualitatif dengan pendekatan Studi Kasus. Dilaksanakan di Palang Merah Indonesia (PMI) Kabupaten Kutai Kartanegara pada bulan November. Jumlah informan 4 orang yang terdiri dari Bidang Quality Control, Kabid Pencarian dan pelestarian donor darah (P2D2S), Bidang penunjang medik dan pendonor darah. Data yang diperoleh melalui wawancara, observasi dan dokumentasi terhadap informan.

Teknik analisis data yang digunakan adalah pola interaksi secara interaktif dan berlangsung secara terus menerus hingga data yang didapatkan sudah jenuh. Miles and Huberman, dalam Sugiyono (2016). Aktivitas dalam analisis yaitu sebagai berikut :

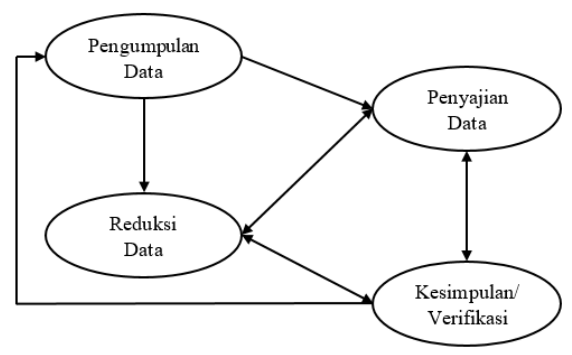

Gambar 1 Pola Interaksi Analisis Data menurut Miles dan Huberman.

Sumber : Prof. Dr. Sugiyono, 2016

\section{HASIL PENELITIAN}




\section{Perencanaan Kebutuhan Darah}

Palang Merah Indonesia (PMI) belum menyusun perencanaan kebutuhan darah berdasarkan PP Nomor 7 Tahun 2011. Pihak PMI hanya menetapkan jumlah minimal darah dan perencanaan bantuan saja. Hal ini dapat dilihat dari pernyataan informan kunci berikut :

“aaa... itu direncana, baru berjalan sekitar dua tahun ini, cuman ituu buat perencanaan bantuan ke pemda aja, dihitung kami, diakumulasikan, minta bantuan sekitar enam bulan kebutuhan PMI.”

\section{W.A.YRW.27}

“Tidak, aa... biasanya kendalanya di lapangan, misalnya panitia, bu nanti siap kantongnya sekitar seratus ya, tapi pas pelaksanaannya kadang tidak sesuai dengan keadaan"

W.A.YRW.12

"Kalau tiga ribuu, inshaallah tercapai, kalau lebih tu biasanya agak agak susah, tergantung donor, pendonornya sih mba"

\section{W.A.YRW.14}

Menurut informan persediaan darah belum sepenuhnya terpenuhi sesuai dengan apa yang telah ditetapkan, sulit untuk mencapai sesuai dengan target. Hal ini dapat dilihat dari pernyataan informan kunci sebagai berikut:

"Biasanya perencanaan kalo misalnya kita donor luar itu yang jelaskan rencananya kalau bisa sebanyakbanyaknya, yaitu tadi kalau misalnya target kita dua lima sampai tiga puluh tidak memenuhi kuota ya mungkin kita agak kurang gitu ya, kurang dapat tapi biasanya inshaallah itu sesuai dengan aa... sesuai dengan apa yang diharapkan, tapi ya kadang-kadang, kadang dapatnya lebih kadang-kadang ya kurang”

\section{W.C.R.16}

"Kalo target darah ya memang kita ada target, tiga ribu lima ratus sampai empat ribu tapi kadang kan jumlah pasien itu tidak bisa diprediksi, em kadang sampai targetnya kadang enda, pasiennya kan aa... turun naik"

\section{W.C.R.18}

"Selanjutnya nii... maunya sih kerjasama, kerjasama antara PMI sama aaa... maksudnya perusahaan atau nda eemm badan, badaan swasta sepertiii kayak wong. Tapi mereka ndabisa, kita ini kan soalnya, nda bisa maksudnya, ndi bisaaa untuk pertiga bulan, mereka cuma bisa pada acara moment ulang tahun mereka aja, kalau untuk pertiga bulan kayaknya mereka harus keluar dana, dana diluar anggaran mereka, jadi kita nda bisa."

W.A.YRW.28

"Darah kosong kalau bisa diantisipasi seperti minta keluarga, pihak keluarga pasien ni. Minta tolong cari pendonor dulu, kalau misalnya nda 
ketemu bisa kita alihkan ke kepolisian, kodim, ke satpol pp. Tapi misalkan dari keempat sumber ini nda bisa mau ke, mau nda mau harus ke samarinda."

W.A.YRW.29

2. Pengerahan dan Pelestarian Pendonor Darah

Kegiatan yang dilakukan Palang Merah Indonesia (PMI) Kabupaten Kutai Kartanegara untuk mengumpulkan pendonor darah yaitu dengan cara donor masal. Hal ini dapat dilihat dari pernyataan informan kunci sebagai berikut :

"kegiatan yang dilakukan biasanya disini mobil unit, kegiatan sosial yang diadakan oleh pihak luar mengundang kami, biasanya sih acara donor masal gitu, dari pihak, pihak misalnya perusahaan, karyawannya gitu yang donor"

W.A.YRW.2

“Biasanya kita ngadakan donor darah masal, biasanya itu aa... perusahaan - perusahaan yang mengundang kita aa... atau organisasiorganisasi merasakat, apa masyarakat” W.C.R.7

"sudah lama sih mba, dulu pernah ikut donor darah diii luar, ada acara donor darah masal, dulu awalnya takut, aa... setelah itu pas pernah donor darah masal sekali kok lihat kayaknya enda, ena aja gitu setelah itu yaudah, mulai dari situ saya berazam rutin aa... dua bulan sekali, dua bulan setengah saya donor, jadi setahun tu kurang lebih empat kali, karena berpikir bahwa banyak banget orang butuh darah, kayak tadi cerita di dalem ternyata darahnya lagi kosong”

W.D.A.5

"Sebenur, sebe..sebenarnya untuk saat ini belum berjalan mba, seper memang harus, harusnya kan sepertiii misalnya donor yang ke tujuh puluh lima itu biasanya temu, temu gubernur atau tidak walikota ya, hee gubernur, cuma disini belum berjalan”

\section{W.A.YRW.8}

"Biasanya kita memberi penghargaan donor, terus mungkin kita dengan mereka donor disini dilayani dengan baik, jangan sampai orang yang menyumbang itu aa... mendapat perlakuan yang tidak enak dalam artian tidak sopan”

W.C.R.11

\section{Penyediaan Darah}

Proses pengambilan darah yang dilakukan di Palang Merah Indonesia (PMI) Kabupaten Kutai Kartanegara sudah memenuhi syarat-syarat yang ada sebelum dilakukan pengambilan darah sesuai dengan peraturan yang ditetapkan. Hal ini dapat dilihat dari pernyataan informan sebagai berikut :

"Kalo syaratnya pendonor harus dalam keadaan sehat pada saat ingin melakukan donor darah, tidak 
mengkonsumsi obat-obatan dalam tiga hari minimal itu, tidak memiliki riwayat penyakit kronis atau penyakit infeksi menular, dan tidur yang cukup minimal lima jam”

\section{W.B.WA.29}

"Yang jelas syarat-syarat untuk donor itu yang pasti sehat, terus tidak minum obat dalaaam satu minggu kecuali vitamin atau pil kb, usia kalo kami disini nerapkan tujuh belas lebih sampai enam puluh, terus berat badan minimal lima puluh, tapi ada sarat-sarat lain misalnya Hbnya minimal dua belas koma lima sampai tujuh belas, tekanan darah seratus lima puluh per seratus atau kalo paling rendahnya seratus per tujuh puluh, wanita tidak lagi haid atau menyusui”

\section{W.C.R.31}

"Biasa mba, rutin dia ngecek kesehatan kita, tensi sama HB, kemudian cek formulir apabila kita punya sakit atau tidak, kemudian biasa sih nanyakan makan terakhir jam berapa, kemudian tadi malam istirahatnya gimana, ya pada dasarnya mereka pengen tau kondisi kita fit atau tidak"

W.D.A.6

"Biasanya sih dilabelnya itu adaa komponen darahnya, tergantung dari rumah sakit, apa yang diminta, terus adaaa nama, nama pasien, nomor ruangan, nomor pdut yang ada di PMI, terus tanggal permintaan darahnya, tanggal kadaluwarsa, nomor kantong, suhu, volum darahnya sama nama pemeriksanya"

W.B.WA.30

"Biasanya kalo tahapan dalam uji saring itu, setelah pengambilan darah bagi pendonor, darah yang didalam kantong tersebut diambil sekitar tiga sampai lima cc, kemudian dimasukan dalam tabung untuk dilakukan pemeriksaan uji saring, nah pemeriksaan uji saring tersebut terdiri dari pemeriksaan HIV, sipilis, HCV, HBSAG setelah dilakukan uji saring tersebut baru kita bisa mendapatkan hasil apakah darah tersebut layak digunakan atau tidak, itu sih”

\section{W.B.WA.8}

"Kalau disini sih sudah ada penyimpanannya buat komponen darah” W.B.WA.22

"Eemm, kalau menurut saya sih sudah memenuhi syarat"

\section{W.B.WA.23}

“Lama penyimpanannya sih tiga puluh lima hari”

\section{W.B.WA.24}

“Ada, ada pernah, kalo trombosit karna kita belum ada mesin pengolahan atau penyimpanan, kalau mesin pengolahan ada cuma kalau penyimpanan, penyimpanan cuma ndabisa bertahan lama ya, cuma kadang ya itu karna kebutuhan sedikit stoknya 
kadang ndada, jadi kalau ada bikin sesuai permintaan"

W.C.R.29

“Diii rumah sakit sih"

W.B.WA.27

"Iyaa"

\section{W.B.WA.28}

“Kalau pemusnahan kita kerjasama dengan rumah sakit, jadii sebulan sekali atau sebulan dua kali kita musnahkan di rumah sakit”

W.C.R.30

"Kendala kita disini, satu, kita gedung masih sistem pinjam pakai, kedua, buat membangun ini pemusnahan darah itu biayanya sangat besar, jadi kita belum ada anggaran untuk itu, paling nda kita gedung dulu, baru pemusnahan hehe"

\section{W.A.YRW.30}

“Nda ada, kita sekedar catatan ini aja sih, catatan kalau darahnya non reakt, reaktif di ini, dicatat, terus yang, yang reaktif aja sih, terus yang kalau transferan itu kan enda”

\section{W.A.YRW.31}

\section{Pendistribusian Darah}

Sebelum darah sampai kepada pasien, di Palang Merah Indonesia (PMI) Kabupaten Kutai Kartanegara melewati beberapa tahapan terlebih dahulu. Hal ini dapat dilihat pada pernyataan informan sebagai berikut :

“Tahapannya tu biasanya dari keluarga pasien yang ada di rumah sakit biasanya datang ke PMI membawa lembaran pdut atau lembaran permintaan darah dan sampel darah, kemudian dari PMI ni mencatat dibuku roster, setelah itu dilakukan uji laboratorium, uji laboratorium itu terdiri dari pengecekan golongan darah, terus pengecekan penyakit infeksi sama uji crossmatch, sela sese selesai melalui uji tersebut baru darah tersebut bisa kita distribusikan ke rumah sakit”

\section{W.B.WA.33}

"Biasanya pendistribusiannya aa... dari rumah sakit mereka mengantar pdut dengan contoh darah baru terus kalo misalnya dicek golongan darah kalo sesuai, kalau stoknya ada langsung kita proses, kalo stok ndada mungkin kita suruh cari pendonor dulu"

\section{W.C.R.15}

\section{PEMBAHASAN}

Pada PP Nomor 7 tahun 2011 Tentang Pelayanan Darah, hal ini tidak dibahas dalam setiap rapat. Pihak PMI hanya menetapkan jumlah minimal persediaan darah, tetapi jumlah tersebut tidak selalu terpenuhi berdasarkan jumlah persediaan yang telah ditetapkan. Sejauh ini pihak PMI menargetkan untuk melakukan kerjasama tetap pertiga bulan dengan pihak perusahaan atau badan swasta, tetapi hal ini belum terselenggara dikarenakan pihak 
perusahaan dan badan swasta tersebut menolak.

Pihak PMI kemudian melakukan perencanaan kembali untuk hal-hal yang belum tercapai, terutama pada jumlah persediaan darah. Tetapi sejauh ini hasil yang didapatkan masih sama, dikarenakan setiap jumlah pendonor pada setiap bulan, tiga bulan atau enam bulan tidak dapat diperkirakan dan jumlah kebutuhan pasien tidak dapat diprediksi.

Hasil penelitian ini serupa dimana dalam proses perencanaan kebutuhan darah telah dilaksanakan tetapi tidak berjalan sesuai dengan apa yang telah direncanakan. Karena perencanaan kebutuhan darah belum terlaksana dengan optimal, maka mengakibatkan ketersediaan darah belum memenuhi standar ideal dan tujuan pengaturan pelayanan darah belum sepenuhnya terlaksana.

Pengerahan pendonor darah merupakan kegiatan yang harus dilakukan untuk mengumpulkan pendonor darah. Di Palang Merah Indonesia (PMI) Kabupaten Kutai Kartanegara belum melaksanakan kegiatan untuk memotivasi dan mengumpulkan pendonor darah secara sukarela, seperti penyuluhan pemberian edukasi terhadap pihak-pihak atau siswa siswi Sekolah Menengah Atas yang telah memasuki usia 17 tahun atau layak menjadi pendonor.
Kegiatan pelestarian pendonor di Palang Merah Indonesia (PMI) Kabupaten Kutai Kartanegara telah direncanakan berupa pemberian penghargaan kepada para pendonor yang telah rutin melakukan donor darah atau sering melakukan donor darah pada waktu yang telah ditentukan. Tetapi dalam hasil wawancara yang telah dilakukan oleh peneliti, bahwa informan mengatakan kegiatan pelestarian pendonor darah berupa pemberian penghargaan kepada pendonor yang rutin melakukan donor darah tersebut belum berjalan sebagaimana mestinya, padahal pada saat wawancara dengan informan mengatakan bahwa sudah ada pendonor yang memenuhi syarat untuk mendapatkan penghargaan pendonor darah rutin.

Penyediaan darah berupa rangkaian kegiatan pengambilan dan pelabelan darah pendonor, pencegahan penularan penyakit, pengolahahan darah, penyimpanan dan pemusnahan darah pendonor. Pengambilan darah pada Palang Merah Indonesia (PMI) Kabupaten Kutai Kartanegara dilakukan oleh tenaga kesehatan, sebelumnya dilakukan pemeriksaan kesehatan pendonor darah terlebih dahulu untuk memastikan apakah pendonor darah tersebut memenuhi syarat dan layak untuk diambil darahnya. Setelah dilakukan pengambilan darah maka petugas melakukan pemeriksaan darah pendonor, jika hasil pemeriksaannya telah dilakukan pemeriksaan lab, lalu hasil 
tersebut diberitahu kepada pendonor darah dengan cara tertutup serta melkukan Standar pelabelan darah guna untuk mencegah darah tertukar, yang memuat keterangan berupa nama, golongan darah, nomor kantong, tanggal permintaan, tanggal kadaluwarsa, dan sebagainya.

Pendistribusian darah merupakan tahapan untuk memenuhi ketersediaan darah yang aman dan sehat kepada pasien yang membutuhkan. Palang Merah Indonesia (PMI) Kabupaten Kutai Kartanegara pendistribusian darah mencakup penyaluran dan penyerahan darah. Darah yang didistribusikan harus memenuhi persyaratan distribusi darah terlebih dahulu. Darah tersebut harus melalui tahapan uji silang terlebih dahulu, jika darah dinyatakan cocok atau sesuai baru darah bisa didistribusikan kepada pasien. Hal ini guna untuk menjamin mutu darah tetap layak hingga ditransfusikan kepada pasien.

\section{KESIMPULAN}

1. Palang Merah Indonesia (PMI)

Kabupaten Kutai Kartanegara belum menyusun perencanaan berdasarkan Peraturan Pemerintah RI Nomor 7 Tahun 2011 Tentang Pelayanan Darah. Pihak PMI hanya menetapkan target jumlah darah dalam setiap kegiatan, tetapi dari setiap target yang ditetapkan tidak selalu terpenuhi. Sumber Daya
Manusia (SDM) dengan jumlah yang ada tidak seluruhnya mendapatkan pelatihan. Sarana dan prasarana serta metode untuk meningkatkan jumlah pendonor darah belum sesuai standar.

2. Pengerahan dan pelestarian pendonor di Palang Merah Indonesia (PMI) Kabupaten Kutai Kartanegara melakukan kegiatan donor luar yaitu donor masal untuk mengumpulkan para pendonor sukarela, tetapi pada setiap kegiatan belum bisa memenuhi target yang telah ditetapkan. PMI telah menerapkan kegiatan mengumpulkan pendonor darah, tetapi belum menerapkan kegiatan mempertahankan pendonor darah.

3. Palang Merah Indonesia (PMI) Kabupaten Kutai Kartanegara telah melaksanakan penyediaan darah, dari segi pengambilan darah, pelabelan darah, pencegahan penularan penyakit, pengolahan darah sampai dengan penyimpanan darah telah di lakukan berdasarkan peraturan yang telah ditetapkan. Hal ini dilakukan guna menjaga darah yang sehat dan aman.

4. Pendistribusian darah di Palang Merah Indonesia (PMI) Kabupaten Kutai Kartanegara telah melakukan pendistribusian darah yang memenuhi standar. Sebelum darah diberikan kepada pasien yang membutuhkan, darah harus melalui tahapan kecocokan 
darah terlebih dahulu. Setelah darah dinyatakan sesuai barulah darah tersebut dapat disalurkan, dengan bukti penyerahan darah kepada Rumah sakit atau pelayanan kesehatan lainnya.

\section{REFERENSI}

Laila Nafisah., Yuli Dwi Astanti., Dini Nastiti (2017). Simulasi Sistem Dinamis Pengendalian Persedian Darah Palang Merah Indonesia Kota Yogyakarta.

Nur.A.P.Utami., Ign. Wagimin., Jumiyanto Widodo. (2012). Manajemen Perbekalan Kantor Palang Merah Indonesia.

Peraturan Pemerintah Republik Indonesia Nomor 7 Tahun 2011 Tentang Pelayanan Darah.

Peraturan Menteri Kesehatan Nomor 83 Tahun 2014 Tentang Unit Transfusi Darah, Bank Darah Rumah Sakit, dan Jejaring Pelayanan Transfusi Darah.

Peraturan Menteri Kesehatan Nomor 91 Tahun 2015 Tentang Standar Pelayanan Transfusi Darah.

Rachman, Fsidikah dan Aditya,Robby N. (2013). Questions \& AnswersDonor Darah. PT. Elex Media Komputindo.

Ria Risti K.D., Martha I.K., Atik Mawarni. (2016). Analisis Kebijakan Donor Darah Dan Implementasi Program Rekrutmen Donor Di Unit Donor Darah (UDD PMI) Kota Pontianak. Volume 4, No 02.
Sabdiah. E Sari., Agus Fitriangga., Iit Fitrianingrum. (2013). Gambaran Pengetahuan, Sikap, dan Tindakan Donor Darah Pada Mahasiswa Fakultas Kedokteran Universitas Tanjungpura Pontianak.

Tofan Sofiansah. (2013). Sistem Informasi Donor Di Unit Donor Darah Palang Merah Indonesia Kota Bandung Berbasis Web. 2089-9033.

Udi. B Harsiwi., Liss. D Arini. (2018). Tinjauan Kegiatan Donor Darah Terhadap Kesehatan Di PMI Karanganyar Jawa Tengah. 20862628. 